\title{
Low Oxygen Treatment prior to cold storage to maintain the quality of peaches
}

\author{
D. Redondo, A. Díaz and J. Val.
}

Plant Nutrition Department. Estación Experimental de Aula Dei (EEAD-CSIC), Avda. Montañana 1005. 50059, Zaragoza, Spain.

\begin{abstract}
High value late season peach cultivars from the region of Aragón (NE, Spain) are appreciated for their delicate flavor, external uniform golden appearance, yellow pulp and chiefly to be free of chemicals as they are bagged from their last three months of growth until harvest. However, their shelf life under storage is very short due to several problems such as loss of firmness, appearance of chilling injuries, incidence of physiological alterations called vitrescent dark spot (VDS) or corky spot (CS) and fungal rots. The research team from Zaragoza has worked for years in the fight against calcium-related physiological disorders in apples by preharvest strategies of foliar calcium treatments. More recently, postharvest treatments with low oxygen at room temperature (LOT) have been successfully applied. However, no reports of these kinds of treatments have been previously reported in late season peaches. Therefore, immediately after harvest, 'Chato' peaches were stored for 2 days at $20{ }^{\circ} \mathrm{C}$ under low $\mathrm{O}_{2}(1-2 \%)$ in Palliflex bags. Thereafter, fruits were cold-stored $\left(0-2{ }^{\circ} \mathrm{C}\right)$ without bag for 40 days and changes were monitored in terms of fruit quality, chilling injuries, incidence of physiological alterations and respiration rates. After 40 days of cold storage, the firmness of treated fruits was the same as at the harvest day, about $41.9 \mathrm{~N}$, meanwhile fruits untreated, decreased to $35.0 \mathrm{~N}$. On the other hand, LOT treatment decrease both the incidence of VDS from 37.9 to $4.0 \%$ and chilling injury severity from 59.3 to $\mathbf{2 0 . 0} \%$. Respiration rates were similar between treatments. Only statistical differences on ethanol production were found: higher in the treated fruits, probably due to the storage temperature the very first $\mathbf{2}$ days, although no odd flavors were found. In conclusion, the application of LOT treatments prior to cold storage may be a promising strategy to preserve fruit quality of late season peach cultivars and deserves further investigation.
\end{abstract}

Keywords: Prunus persica, fruit firmness, vitrescent dark spot, Palliflex $\mathbb{C}$, chilling injury.

\section{INTRODUCTION}

High value late season peach cultivars (Prunus persica L. Batsch.) from the region of Aragón (NE, Spain) are appreciated by the consumers because of their excellent aspect and organoleptic characteristics. The fruit of these clingstone cultivars has round shape, light yellow skin without red spots and very low pubescence. The fruit flesh is yellow, non-melting and firm with high sugar content and chiefly to be free of chemicals as they are bagged from their last three months of growth until harvest (Oria, 2001). 
These fruits have the problem that their shelf life under cold storage is very short due to the loss of firmness, the appearance of chilling injuries, the incidence of physiological alterations called vitrescent dark spot (VDS) or corky spot (CS), and the presence of fungal rots (Crisosto et al., 2008, Fernandez et al., 2012). Different strategies have been applied to reduce these alterations, most of them related to calcium (Conway et al., 1994, Val et al., 2010). Calcium is one of the limiting factors affecting fruit quality, in fact, is a key element in relation to firmness. Moreover, a higher concentration of calcium in fruit tissues provides commodities with a greater self-life, decreasing the probability of occurrence of physiological disorders that cause heavy losses to the fruit sector (Val et al., 2016). Therefore, it has been demonstrated that an effective solution to prevent these disorders consist on the direct applications of calcium on the fruit surface, increasing the concentration of this nutrient in tissues of fruits as apples and peaches (Val et al., 2008, Val et al., 2010). On the other hand, postharvest treatments with low oxygen at room temperature (LOT) have been successfully applied in apples. Apple storage at low $\mathrm{O}_{2}$ hampers the production of ethylene (Gorney et al., 1997, Stow et al., 2000), controls biotic disorders as an alternative to the use of agrochemicals (Chervie et al., 1997, Ke et al. 1992, Liu et al., 2008), decreases apple scald (Lurie et al., 1992, Wang et al., 2000, Zanella et al., 2003, Pesis et al., 2007), and reduces bitter pit incidence (Val et al., 2010) during cold storage thereby extending the storage life of this fruits. However, evaluation of these kind of treatments have not been reported in late season peaches.

\section{MATERIALS AND METHODS}

\section{Fruit samples}

Late season peaches (Prunus Persica L. Batsch 'Chato') were manually harvest at random in a commercial orchard located in the Mid-Ebro Valley (Caspe, Zaragoza, Spain) on October 25, 2016. The samples were transferred immediately to the facilities of Agricola Gil Company (Urrea de Jalón, Zaragoza, NE Spain) where the LOT was carried out.

\section{Experimental design}

The fruits where divided in two groups: control batch and LOT batch. Control samples were stored at $0-1{ }^{\circ} \mathrm{C}$ and $85 \% \mathrm{RH}$ for 40 days. On the other hand, LOT samples were stored under low $\mathrm{O}_{2}(0-1 \%)$ at room temperature $\left(20^{\circ} \mathrm{C}\right)$ in Palliflex bags for 2 days. Thereafter, fruits were cold-stored $\left(0-2{ }^{\circ} \mathrm{C}\right)$ without bag for 38 days and changes were monitored. Quality analyses were performed at harvest and after 20 and 40 days of storage.

\section{Quality parameters}

To evaluate quality parameters (destructive and non-destructive) 20 fruits per experimental unit were analyzed. The color coordinates were determined using the CIELab color space with the aid of a spectrophotometer (Konica Minolta mod. CMS 700; Tokyo, Japan). Firmness was measured with a destructive Magness-Taylor measurement using a digital penetrometer (Agrosta; Forges Les Eaux, France) with a tip diameter of 8 $\mathrm{mm}$ and expressing the results as $\mathrm{N}$. Soluble solid content (SSC) expressed as ${ }^{\circ}$ Brix was 
determined by crushing the flesh and transferring the intact juice of the 10 samples to a digital refractometer (Atago mod. PR-101; Tokyo, Japan). Titratable acidity (TA) was measured using an automatic titrator (Mettler Toledo mod. G20 Compact Titrator; New York, NY, USA). 10 grams of juice of 10 fruits were added to $60 \mathrm{~mL}$ of distilled $\mathrm{H}_{2} \mathrm{O}$ and titrated with $0.1 \mathrm{M} \mathrm{NaOH}$ solution up to $\mathrm{pH}$ 8.1, expressing the results as malic acid content on a fresh weight basis $\left(\mathrm{g} \mathrm{kg}^{-1}\right)$.

\section{Respiration rates}

For the measurement of respiratory activity and ethylene concentration, a sample of three intact peaches was sealed in a glass jar and kept at $20^{\circ} \mathrm{C}$ for 3 hours. The headspace gas composition was analyzed for $\mathrm{O}_{2}$ and $\mathrm{CO}_{2}$ with an automatic gas analyzer (PBI Dansensor; Barcelona, Spain) and for ethylene concentration by gas chromatography (Hewlett Packard 4890) with a flame ionization detector (FID) and a stainless steel column (Hewlett Packard 19001 A-QSO, 80/100 Porapak QS packing). Injector, detector and oven temperatures were set at 50,200 , and $50{ }^{\circ} \mathrm{C}$, respectively, and the carrier gas was nitrogen. Measurements were made in triplicate for each batch and the results expressed as $\mathrm{mL} \mathrm{kg}^{-1} \mathrm{~h}^{-1}$ for $\mathrm{O}_{2}$ and $\mathrm{CO}_{2}$ and as $\mu \mathrm{L} \mathrm{kg}^{-1} \mathrm{~h}^{-1}$ for ethylene. All determinations were performed at atmospheric pressure and room temperature.

For ethanol and acetaldehyde, $20 \mathrm{~mL}$ of juice was extracted from $100 \mathrm{~g}$ of pulp and transferred to $40 \mathrm{~mL}$ amber-colored tubes. Each tube was hermetically closed with a screw top containing a silicon septum, and was then held in a water bath for $60 \mathrm{~min}$ at 60 ${ }^{\circ} \mathrm{C}$. Samples $(1 \mathrm{~mL})$ of the headspace were taken through the septa with a Hamilton gastight syringe and were injected into a the previous gas chromatograph. Injector, detector and oven temperatures were set at 50,200 , and $100^{\circ} \mathrm{C}$, respectively, and the carrier gas was nitrogen. Every result was the average of three replicates of $100 \mathrm{~g}$ pulp and the data expressed as $\mu \mathrm{Lg}^{-1} \mathrm{~h}^{-1}$.

\section{Physiological alterations}

After 40 days of cold storage, the incidence of chilling injury was evaluated by splitting the peach in two halves. The percentage of browning was estimated on the surface exposed (Grade 0: healthy; Grade 1: $<25 \%$ pulp surface affected; Grade 2: 2550\% pulp surface affected; Grade 3: $>50$ pulp surface affected) and the vitrescent dark spot (VDS) (affected or healthy) was evaluated in 30 fruits per batch. With this classification, severity index was calculated as follows:

Severity Index (\%): $\frac{(\% \text { Grade } 0 * 0)+(\% \text { Grade } 1 * 1)+(\% \text { Grade } 2 * 2)+(\% \text { Grade } 3 *)}{3}$

\section{Sensory analysis}

A descriptive test was done with a trained panel. Ten participants (4 men and 6 women) that had already participated in sensory sessions in the past formed this panel. The panel was trained for quantitative descriptive analysis and the components received three 60-min training sessions prior to formal sessions. The selected parameters for the visual phase were firmness to the touch and visual aspect and for the taste phase were texture, crunchiness, juiciness, and flavor intensity. All these parameters were assigned values on a scale from 0 to 10 . 


\section{Statistical analysis}

All samples were analyzed in triplicate each year and the results presented as mean values \pm standard deviation. Statistical analyses were performed using a one-way ANOVA test and the significance of the difference between means was determined by Duncan's multiple range test $(p<0.05)$. Statistical analysis was performed using the Statistical Package for the Social Science (SPSS) software version 22.0.

\section{RESULTS AND DISCUSSION}

Table 1 shows the evolution of some quality parameters of 'Chato' peaches at the date of harvest and after 20 and 40 days of cold storage. No changes in non-destructive firmness (Aweta) and the $\mathrm{L}^{*}$ coordinate were registered since the day of receipt to the end of the evaluation period. However, there were statistically significant differences $(p \leq 0.05)$ in acidity (decrease) and soluble solids (increase) and therefore, in the SS/Acidity ratio, as well as an increase in the color coordinate $\mathrm{a}^{*}$ and a decrease in $\mathrm{b}^{*}$, which indicate the generation of darker orange tones. LOT did not induce any quantitative differences with respect to control samples at 20 nor at 40 days of storage.

\begin{tabular}{|c|c|c|c|c|c|c|}
\hline & Aweta & $\begin{array}{l}\text { SSC } \\
\left({ }^{\circ} \text { Brix }\right)\end{array}$ & $\begin{array}{c}\text { TA } \\
\left(\mathrm{g}_{\left.\text {malic acid } \mathrm{kg}^{-1}\right)}\right)\end{array}$ & $L^{*}(D 65)$ & $a^{*}(D 65)$ & $b^{*}(D 65)$ \\
\hline \multicolumn{7}{|c|}{ is 5} \\
\hline & 20.7 & $11.9 \mathrm{~b}$ & $4.2 \mathrm{a}$ & 68.6 & $6.1 \mathrm{c}$ & $46.0 \mathrm{a}$ \\
\hline \multicolumn{7}{|l|}{ T20 } \\
\hline Control & 17.5 & $12.3 a b$ & $2.7 \mathrm{~b}$ & 68.2 & $15.5 b$ & $43.3 \mathrm{~b}$ \\
\hline LOT & 18.1 & $12.1 \mathrm{ab}$ & $2.7 \mathrm{~b}$ & 67.7 & $15.8 \mathrm{~b}$ & $44.8 \mathrm{ab}$ \\
\hline \multicolumn{7}{|l|}{ T40 } \\
\hline Control & 17.3 & $12.9 \mathrm{a}$ & $2.5 \mathrm{~b}$ & 67.5 & $18.1 \mathrm{a}$ & $42.7 \mathrm{bc}$ \\
\hline LOT & 18.6 & $12.6 \mathrm{a}$ & $2.4 \mathrm{~b}$ & 67.6 & $17.2 \mathrm{a}$ & $42.9 \mathrm{bc}$ \\
\hline
\end{tabular}

If we focus on analyzing the evolution of destructive firmness throughout cold storage (Figure 1), we can observe that the firmness of LOT treatment is higher that the control treatment both at 20 and 40 days. This may indicate that the LOT is able to influence the firmness of peaches, a finding that had already been reported in apples by our research group (Val et al., 2010; Pérez et al., 2012; Pérez et al., 2016). 


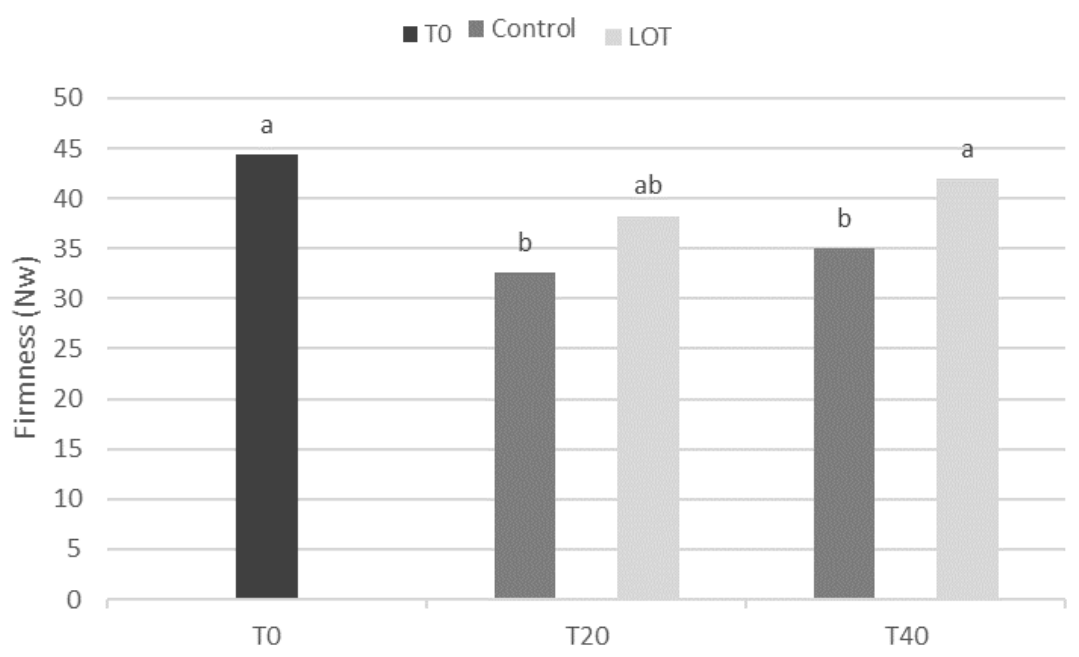

Figure 1. Evolution of firmness (destructive) in 'Chato' peaches. Different letters indicate significant differences $(p \leq 0.05)$ between treatments.

The evaluation of the physiological alterations present in these fruits after 40 days of preservation is shown in Table 2. It can be observed that LOT fruits developed lower incidence of VDS $(4.0 \%)$ and chilling injury (55.8\%) than control fruits $(38.9 \%$ and $88.9 \%$, respectively). Moreover, the severity of chilling injury was 3 times lower in treated samples that non-treated.

\begin{tabular}{|c|c|c|c|c|c|}
\hline & \multicolumn{2}{|c|}{ VDS } & \multicolumn{3}{|c|}{ Chilling injury } \\
\hline & Healthy & Affected & Healthy & Affected & Severity Index \\
\hline \multicolumn{6}{|l|}{ T40 } \\
\hline Control & 61.1 & 38.9 & 11.1 & 88.9 & 59.3 \\
\hline LOT & 96.0 & 4.0 & 44.2 & 55.8 & 20.0 \\
\hline Sign. & 0.001 & 0.001 & 0.001 & 0.001 & 0.001 \\
\hline
\end{tabular}

With slight changes over time, both the concentrations of $\mathrm{CO}_{2}$ generation and $\mathrm{O}_{2}$ consumption were always higher in control samples (FIg. 2A). However, only statistical differences between treatments were recorded in $\mathrm{O}_{2}$ consumption after 40 days of storage. The production of ethylene (Figure 2B) increased over time (which is typical on stone fruits) and was higher in the LOT batch, with no statistical differences between treatments. Regarding the production of acetaldehyde and ethanol (Figure 2C), compounds related to the appearance of anomalous flavors or aromas during storage, the acetaldehyde content in LOT samples was higher after 40 days of conservation, but the most remarkable fact is the high production of ethanol in the LOT treatment. This effect could be due to the low concentrations of $\mathrm{O}_{2}$ and $\mathrm{CO}_{2}$ and the temperature of the LOT during the first 2 days that lead to different fermentation reactions inside the fruit. However, the sensorial analysis of these fruits did not revealed off flavors or fermented aromas. The trained panel found better visual aspect for the LOT samples after 20 and 40 
storage days, and also better firmness to the touch, texture and crunchy than the control fruits, and no off-flavor detected (Table 3).

\begin{tabular}{|c|c|c|c|c|c|c|}
\hline & $\begin{array}{l}\text { Visual } \\
\text { aspect }\end{array}$ & $\begin{array}{l}\text { Firmness to } \\
\text { the touch }\end{array}$ & Texture & Crunchy & Juiciness & $\begin{array}{c}\text { Flavor } \\
\text { intensity }\end{array}$ \\
\hline \multicolumn{7}{|l|}{ TO } \\
\hline & 8.6 & 9.1 & 8.6 & 9.3 & 2.1 & 6.2 \\
\hline \multicolumn{7}{|l|}{$\mathrm{T} 20$} \\
\hline Control & 7.1 & 5.7 & 7.1 & 6.1 & 3.2 & 6.4 \\
\hline LOT & 7.6 & 7.3 & 7.9 & 6.2 & 2.9 & 5.8 \\
\hline \multicolumn{7}{|l|}{$\mathrm{T} 40$} \\
\hline Control & 5.6 & 4.9 & 5.2 & 3.8 & 5.1 & 6.9 \\
\hline LOT & 6.8 & 6.8 & 6.4 & 4.9 & 4.1 & 6.7 \\
\hline
\end{tabular}




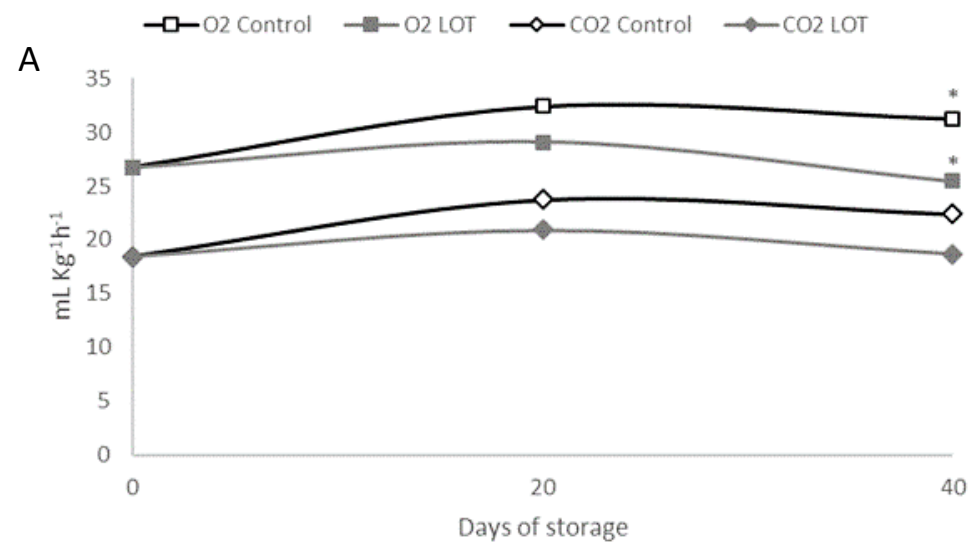

B

$\rightarrow$ Ethylene Control $\quad-$ Ethylene LOT

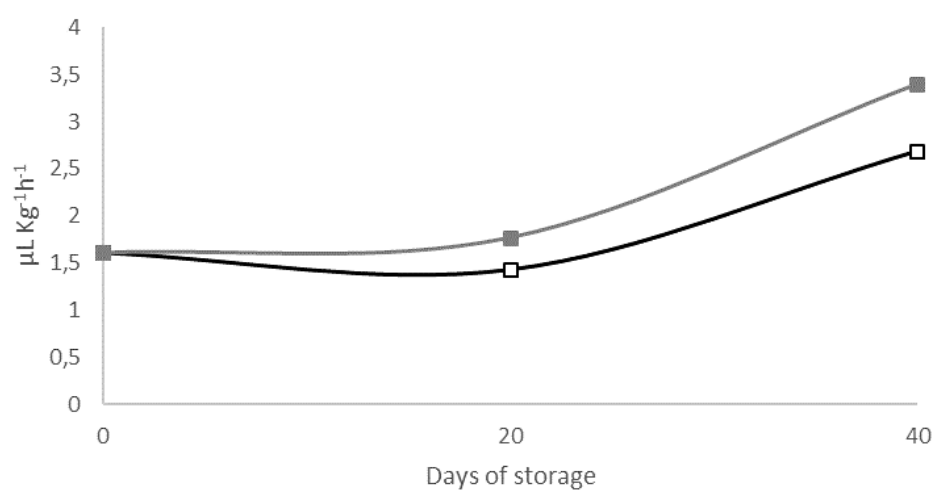

C

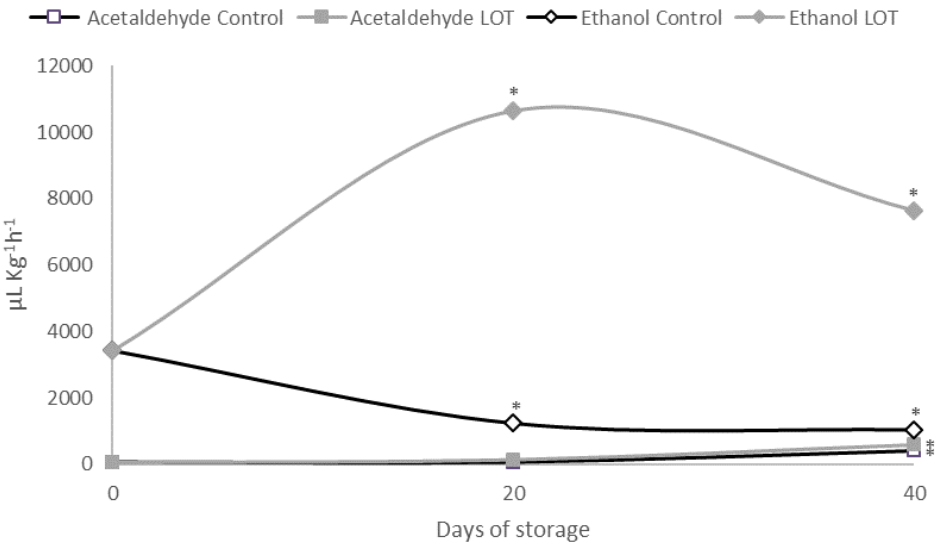

Figure 2. Evolution of $\mathrm{O}_{2}$ and $\mathrm{CO}_{2}(\mathrm{~A})$, ethylene (B) and acetaldehyde and ethanol (C) in 'Chato' peaches after LOT. *Significant differences $(p \leq 0.05)$ between treatments.

Our results indicate that the application of LOT technology prior to cold storage may be a promising strategy to preserve fruit quality of late season peaches and deserves further investigation. In addition, these low-impact procedures are environmentally friendly and do not require the addition of chemical compounds to preserve fruit quality. From this study, we are able to propose the following conclusions: 
- The application of low oxygen treatment during 2 days at room temperature is effectively maintained destructive firmness after 20 and 40 days of storage, with no effect in the rest of quality parameters.

- LOT reduce incidence of vitrescence dark spot and chilling injury in peaches. The visual aspect of the treated fruits was better than the control fruit.

- Control fruits exhibited higher consumption of $\mathrm{O}_{2}$ and produced more $\mathrm{CO}_{2}$ than LOT samples, although the highest concentration of ethanol was recorded for LOT samples.

- Sensorial analysis shows better ratings for LOT samples for firmness, texture and crunchy than control fruits.

- LOT treatments prior to cold storage may be a promising strategy to preserve fruit quality of late season peach cultivars

\section{ACKNOWLEDGEMENTS}

This work has been funded by the following grants: 'Mejora de la calidad del melocotón de Calanda: material vegetal, técnicas culturales, conservación y comercialización'; 'Mejora Genética de patrones Prunus y variedades de melocotonero' (AGL2014-52063-R); and also by the Department of Innovation, Research and University of the Government of Aragon and the European Social Fund.

\section{Literature Cited}

Conway, W.S., Sams, C.E., and Kelman, A. (1994). Enhancing the natural resistance of plant tissues to postharvest diseases through calcium applications. HortScience 29, 751-754.

Chervin, C., Kulkarni, S., Kreidl, S., Birrell, F., and Glenn, D.A. (1997). A high temperature/low oxygen pulse improves cold storage disinfestation. Postharvest Biol Technol. 10, 239-245. http://doi.org/10.1016/S09255214(96)01401-9.

Crisosto, C., and Costa, G. (2008). Preharvest Factors Affecting Peach Quality. In: The peach: botany, production and uses, D. Layne and D. Bassie, eds. (England, Wallingford: CABI), pp. 536-549. DOI:10.1079/9781845933869.0536.

Fernandez, V., Blanco, A., and Val, J. (2012). Vitrescent dark spot in peach: a preliminary mineral element characterization. Acta Hortic. 962, 495-498. http://dx.doi.org/10.17660/ActaHortic.2012.962.67.

Gorney, J.R. and Kader A.A. (1997). Low oxygen and elevated carbon dioxide atmospheres inhibit ethylene biosynthesis in preclimacteric and climacteric apple fruit. J Am Soc Hortic. Sci. 122, 542-546.

Ke, D., and Kader, A.A. (1992). External and internal factors influence fruit tolerance to low-oxygen atmospheres. J Am Soc Hortic Sci. 117, 913-918.

Liu, Y.B. (2008). Ultralow oxygen treatment for postharvest control of western flower thrips, Frankliniella occidentalis (Thysanoptera: Thripidae), on iceberg lettuce. I. Effects of temperature, time, and oxygen level on insect mortality and lettuce quality. Postharvest Biol Technol. 49, 129-134. http://doi.org/10.1016/j.postharvbio.2007.12.009.

Lurie, S., and Pesis. E. (1992). Effect of acetaldehyde and anaerobiosis as postharvest treatments on the quality of peaches and nectarines. Postharvest Biol Technol. 1, 317-326. http://doi.org/10.1016/09255214(92)90034-M.

Oria, R. (2001). Tecnología postcosecha: Mantenimiento postcosecha de la calidad del Melocotón de Calanda. Informaciones técnicas. 96, 1-20.

Pérez M, Díaz A, Blanco A, Remón S, Val J. (2012) Tratamientos físicos postcosecha para mejorar la calidad de la manzana Golden. En: Avances en poscosecha de frutas y hortalizas, Recasens I, Graell J, Echeverría (eds): pp. 451-456. Edicions de la Universitat de Lleida 
Pérez, M., Remón, S., Díaz, A., Redondo, D., and Val, J. (2016) Tratamientos físicos de bajo impacto para mitigar alteraciones fisiológicas de las manzanas. Actas Portuguesas de Horticultura. 28: 139-145.

Pesis, E., Ben-Arie, R., Feygenberg, O., Lichter, A., Gadiyeva, O., Antilofyev, I. and Uryupina, T. (2007). A simple pretreatment with low 02 to alleviate superficial scald in Granny Smith apples. J Sci Food Agric. 87, 18361844. http://doi.org/10.1002/jsfa.2873.

Stow, J.R, Dover, C.J., and Genge, P.M. (2000). Control of ethylene biosynthesis and softening in 'Cox's Orange Pippin' apples during low-ethylene, low-oxygen storage. Postharvest Biol. Technol. 18, 215-225. http://doi.org/10.1016/S0925-5214(99)00082-4.

Val, J., Fernández, V., López, P., Peiró, J. M., and Blanco, A. (2010). Low oxygen treatment prior to cold storage decreases the incidence of bitter pit in 'Golden Reinders' apples. J. Science Food Agr., 90(3), 536-540.

Val, J., Monge, E., Blanco, A., and Espada, J.L. (2010). The effects of Ca applications on peach fruit mineral content and quality. Acta Hortic. 868, 405-408. http://dx.doi.org/10.17660/ActaHortic.2010.868.55.

Val, J., Monge, E., Risco, D., and Blanco, A. (2008). Effect of pre-harvest calcium sprays on Calcium concentrations in the skin and flesh of apples. J. Plant. Nutr. 31, 1889-1905. http://dx.doi.org/10.1080/01904160802402757.

Val, J., del Río, S., Redondo, D., and Díaz, A. (2016) Novel exogenous calcium treatment strategies effectively mitigate physiological disorders in late season peach cultivars. VIII International Postharvest Symposium. P.9 Poster.

Wang, Z., and Dilley, D.R. (2000). Initial low oxygen stress controls superficial scald of apples. Postharvest Biol Technol. 18, 201-213. http://doi.org/10.1016/S0925-5214(00)00067-3

Zanella, A. (2003). Control of apple superficial scald and ripening: a comparison between 1methylcyclopropene and diphenylamine postharvest treatments, initial low oxygen stress and ultra-low oxygen storage. Postharvest Biol. Technol. 27, 69-78. http://doi.org/10.1016/S0925-5214(02)00187-4. 